\title{
Development of Students' Intellectual Activity and Creativity Program
}

\author{
Pardomuan Nauli Josip Mario Sinambela \\ Department of Mathematics Education \\ Universitas Negeri Medan \\ Medan, Indonesia \\ pardomuannjmsinambela@gmail.com
}

\author{
Irwasnyah Siregar \\ Faculty of Sport Science \\ Universitas Negeri Medan \\ Medan, Indonesia \\ Irwansyahsiregar02@gmail.com
}

\author{
Rahman Situmeang \\ Faculty of Sport Science \\ Universitas Negeri Medan \\ Medan, Indonesia \\ rahmansitumeang@gmail.com
}

\begin{abstract}
This study aimed to produce of product find of development of students' intellectual activity and creativity program. This study is applied to accomplish the above objective, used method of research and development. The stages of developing the program are surveys, planning, validation, and socializing. The subject of the study were students of Universitas Negeri Medan (Unimed). Program of intellectual activity and creativity current runs without consider about some aspects among others planning, implementation and evaluation of activities. The final product of this research was the valid program about intellectual activity and creativity student.
\end{abstract}

Keywords—intellectual activity; creativity

\section{INTRODUCTION}

Intellectual activity is very important for students to be able to create students who have high creativity. Reasoning is something that is done in the brain which is based on empirical observation that produces several concepts.

Reasoning and creativity are absolutely necessary not only in educational institutions, but also at home and in the social environment. At present, it is not only early childhood or adolescence that requires reasoning and creativity but also adult age. This shows that reasoning is needed for the survival of an Indonesian nation. The era of globalization is increasingly demanding the need for reasoning and creativity so that graduates at various levels of education can compete with other people in various parts of the world.

The human resource structure of the next few years requires good intellectual activity and high creativity. Individual success is also determined by the reasoning and creativity it has. Good reasoning and creativity can be developed through the development of the right program. It can be said that reasoning is a process of thinking which starts from the observation of the senses which produces a number of concepts and understanding. Based on similar observations, similar propositions will be formed. Based on a number of propositions that are known or considered to be true, one can deduce a new proposition that was previously unknown. This process is called reasoning. Creativity is the ability to create something new to give creative ideas in solving problems or as the ability to see new relationships between elements that already existed before. Another opinion about creativity is all one's ability to create something new, both in the form of ideas and real works that are relatively different from what was before.

Based on research conducted in India, it was stated that in the real world humans must be able to use reasoning skills all the time. This shows that reasoning is very important to deal with an uncertain life. This also shows that one's success is not solely determined by knowledge and technical abilities and cognition, but also the way of reasoning and creativity that can be demonstrated.

Universities have a role in improving students' reasoning and creativity, one of them is by integrating it naturally with the standard curriculum. This is better compared to adding a series of separate meetings in the actual curriculum that are already very solid, an easy choice is to integrate with the courses in all classes by all lecturers. Therefore, it is deemed necessary to have a university policy in developing programs to improve students' reasoning and creativity at the University.

\section{LITERATURE REVIEW}

\section{A. Intellectual Activity}

Reasoning is a thought process that starts from sensory observation which produces a number of concepts and understanding. Reasoning is a thought process that attempts to connect the facts that are known to lead to a conclusion. Reasoning is a particular thinking activity to find the truth.

The reasoning product is knowledge that is related to thinking activities not emotional activities. The activity of 
thinking in reasoning does not include feelings. Not all activities rely on reasoning. Reasoning is an activity of thinking that has two characteristics, namely 1) the existence of a mind-sets of logic, 2) the analytic nature of the human thinking process. The way of thinking of a society can be categorized as i) analytic thinking in the form of reasoning, ii) non-analytic thinking in the form of intuition or feeling. [1]

Based on previous opinions it is clear that not all human thinking activities are logical and analytical. Both must walk at the time and when needed. Thinking and reasoning is the activity of reason to associate, analyse, and formulate antithesis and synthesis to obtain new conclusions and understandings based on the memory data that is owned. Memory and analysis are two parts that cannot be separated in the process of thinking, and this is what is commonly called cognitive ability.

Reasoning is needed to know whether an argument is right or wrong. Reasoning is also important to verify program checking and inference of an intelligence system. There are several terms used in reasoning namely syllogism, entimen, and generalization. Syllogism is a deductive process of drawing conclusions. Syllogism is composed of two statements and a conclusion (conclusion). With another fact that syllogism is a series of 3 opinions, consisting of 2 opinions and 1 conclusion. Entimen is direct deduction reasoning. And it can also be said that the syllogism of the premise is omitted or not pronounced because it is equally known. Generalization is a statement that is generally applicable to all or most of the symptoms that are in favor of generalization including essential features, not details. In the development of essays, generalizations are proven by facts, examples, statistical data, and others.

In general, reasoning does not pay attention to the development of a person's ability which is very influential on the achievements he achieved. Therefore reasoning is something that is very important can be used to solve the problems it faces. Given how important this aspect of reasoning is, it is necessary to develop student reasoning abilities. If students' reasoning abilities are not developed, then everything will only become a series of procedures and imitate without knowing the meaning of something.

Here are two types of reasoning, namely inductive reasoning and deductive reasoning. Inductive reasoning is a thought process that is used to draw conclusions but is not proof, because inductive reasoning begins by expressing statements that have a specific and limited scope in preparing arguments that end with a general statement. Inductive thinking is a method used in thinking by starting from specific things to the public. Generalization is a form of inductive reasoning. Deductive reasoning is a way of drawing conclusions that turn from inductive to conclusions drawn from general matters to specific cases. Deductive deduction of conclusions usually uses a syllogistic mind-sets, two statements and a conclusion, and in the syllogism there is a major premise and a minor premise.

Based on this explanation it can be concluded that reasoning consists of inductive reasoning and deductive reasoning. Inductive reasoning is a thought process that is carried out to draw conclusions from the general to the public. Deductive reasoning is drawing conclusions from general to specific. The field program of student activities must be able to design a program so that it can improve student reasoning both through two types of reasoning. Furthermore, the student is said to have good reasoning if he is able to use reasoning in patterns, traits, manipulations, and generalizations, compile evidence, and explain ideas and statements in reasoning and creativity activities.

\section{B. Creativity}

In the Big Indonesian Dictionary Creativity is the ability to create [2]. Creativity can also mean as the latest and original creations created, because creativity is a unique mental process to produce something new, different and original. Creativity is a regular, comprehensive, and imaginative brain activity towards an original result. Creativity is a process of forming something new, interesting, response, outcome or solution of a open-ended problem [3].

Creativity is the ability of a person to give birth to something new, both in the form of ideas and real work that is relatively different from what already exists. Creativity is a high-level thinking ability which implies an escalation in thinking ability, characterized by succession, discontinuity, differentiation, and integration between stages of development [4].

The definition of creativity that represents a consensual definition and conceptual definition is creative work is a new work that is accepted as being defensible or useful or satisfying by a group at some point in time [5]. Creativity is an experience in expressing and actualizing an individual's identity in an integrated form between self, nature and others. [6].

Creativity is a plural and multi-dimensional concept, making it difficult to define operationally [7]. A simple definition that is often used widely about creativity is the ability to create something new. Creative products are created. The product itself is very diverse, ranging from mechanical discoveries, new chemical processes, new solutions or new statements about a problem in mathematics and science; fresh music composition, short story poetry or evocative novels that have never been written before; painting with a new perspective; sculpture or potography that did not exist before; up to a breakthrough in the rule of law, religion, philosophy, or new patterns of behavior.

The characteristics of creativity can be grouped into two categories, cognitive and non-cognitive [8]. Cognitive characteristics include originality, flexibility, fluency, and elaboration. While non-cognitive characteristics include motivational attitudes and creative personality. Both of these characteristics are equally important, intelligence that is not supported by creative personality will not produce anything. Creativity can only be born of intelligent people who have healthy psychological conditions. Creativity is not only the work of the brain but emotional and mental health variables greatly influence the birth of a creative work. Intelligence without healthy mentality can be very difficult to produce creative work.

Based on some of the definitions above it can be concluded that creativity is an individual mental process that produces effective new ideas, processes, methods or products that are imaginative, flexible, succession, and discontinuity, 
which are useful in various fields to solve a problem. So creativity is part of one's business. Creativity will be an art when someone does an activity.

\section{METHOD}

\section{A. Type of Research}

Based on the formulation of the problem and the stated research objectives, this research includes development research. The product of this research is the formation of a program that is the reasoning and creativity of students in Unimed.

\section{B. Research Procedures and Design}

This research is a Borg and Gall development research, which aims to improve the quality of education. In addition to developing and validating educational outcomes, this development research is used to develop programs that can enhance the reasoning and creativity of Unimed students. The research method used is qualitative to see the implementation of program indicators, student responses, and changes in student reasoning and creativity. Educational research and development ( $R$ \& D) is a process used to develop and validate product of education [10]. Based on the quotation, research and development are carried out cyclically and at each step that will be carried out refers to the previous results until it produces a new program.

Borg and Gall proposed a series of steps that must be taken in this approach, namely "research and information collecting, planning, develop preliminary form of product, preliminary field testing, main product revision, main field testing, operational product revision, operational field testing, final product revision, and dissemination and implementation". Conceptually, the research and development approach to be carried out is presented in the following figure.

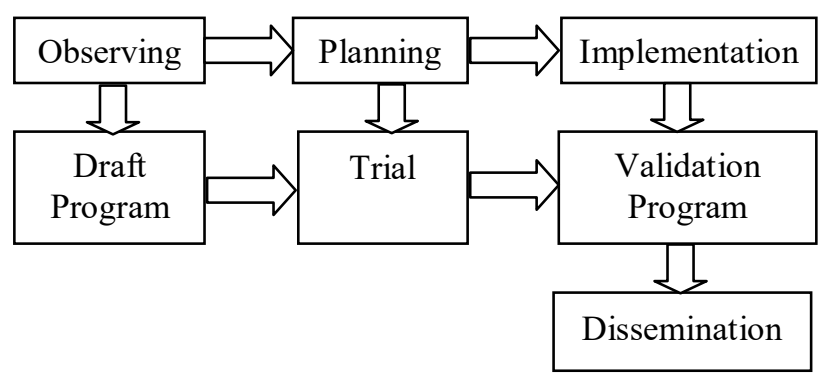

Fig 1. Research Design of Students' Intelectual Activity and Creativity

\section{RESULT AND DISCUSSION}

The development of a program includes a cycle that involves planning, implementing, monitoring, and evaluating. Each of these stages requires a mature design to ensure program achievement and anticipate various external changes that may occur during program implementation.

The direction of the student activity program was developed through several fields including a) the field of reasoning and creativity development, b) the field of welfare and entrepreneurship, c) areas of interest, talent, and organization, d) the field of career alignment and development, e) the field of spiritual / religious mental development and state / national / Indonesian defense, f) internationalization. The six directions of the student activity program are presented in the following figure [10].

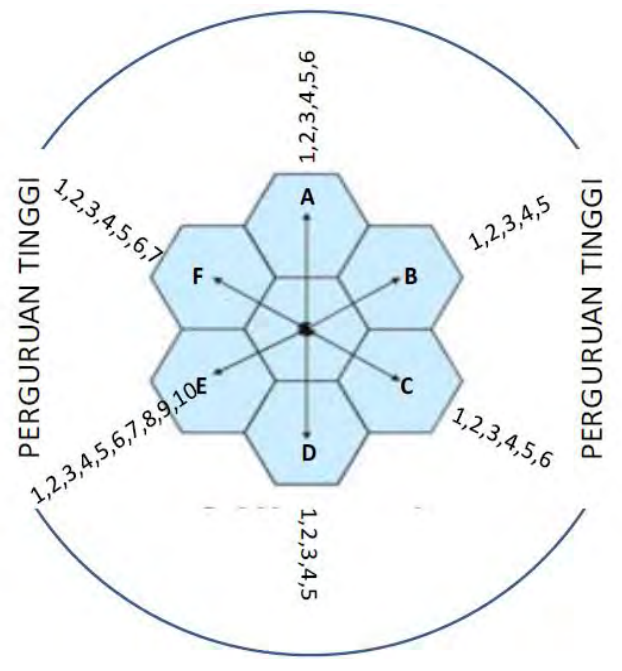

Fig 2. hexagonal student program

Intellectual activity and creativity program is an important issue that must be developed because this field is one of the problems that need to be improved in quality and quantity in Unimed. Program development in the field of reasoning and creativity aims to stimulate, develop, and foster students' abilities in professional scientific insights and attitudes developed through several activities. The field of development of reasoning and creativity in the Ministry of Research and Higher Education of the Republic of Indonesia includes 1) Mathematics Olympiad and College Science (ON MIPA PT), 2) National University Debate Championship (NUDC), 3) Selection of Outstanding Students (Pilmapres), 4) Week of Student Creativity (PKM), 5) National Student Science Week (Pimnas), 6) Indonesian Robot Contest (KRI), 7) Indonesian Flying Robot Contest (KRTI), 8) ICT Student Performance (Gemas TIK), 9) Energy Saving Car Contest (KMHE), 10) Unmanned Fast Boat Contest (KKCTB), 11) Indonesia Bridge Competition (KJI) and Indonesian building contest (KBGI), 12) student critical thinking competition (KPKM).

Student affairs in Unimed have responsibility to implemented and achievement of the programs in the student unit Unimed, both routine programs of Ministry of Technology Research and Higher Education, even programs that are designed by department or faculty in Unimed.

Based on the analysis of theoretical of development program and way of student intellectual activity and creativity program, researchers designed a program according to indicators of intellectual activity and creativity as follows: 


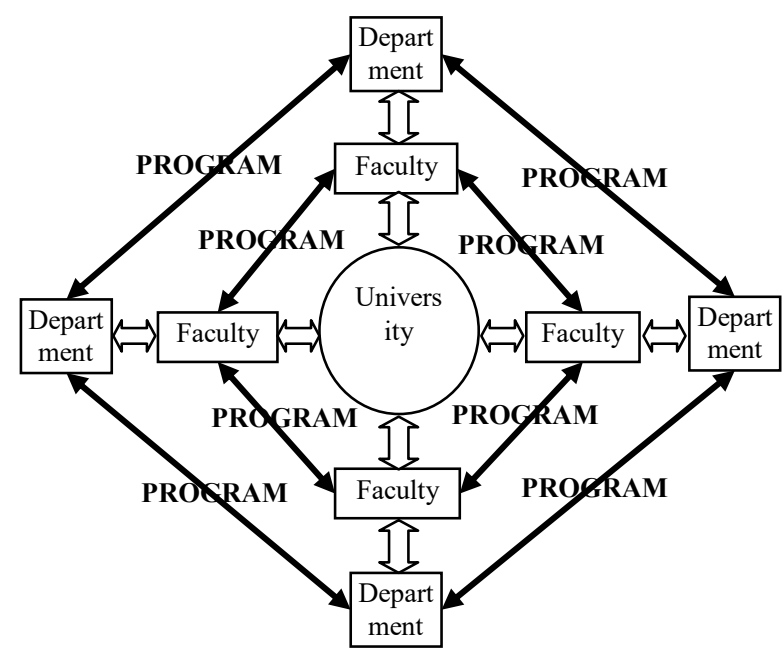

Fig 3. development program of students' intelectual activity and creativity

\section{CONCLUSION}

Formulation of the problem and the purpose of this research is to produce the development of intellectual activity and creativity program at Unimed. Thus, the conclusions of this study are follows: 1) the intellectual activity and creativity program is one of the flagship programs in the field of student affairs from the Ministry of Technology Research and Higher Education which must be developed by universities based on 12 main activities, 2) program of intellectual activity and creativity development involves collaboration between departments, between faculties and accommodated by universities, 3) this intellectual activity and creativity program is still in the process of development and is still in the validation stage by experts so that it is possible that there will still be further improvements from the results of this study

\section{ACKNOWLEDGMENT}

This research was supported by research institutions of Universitas Negeri Medan. We thank our colleagues Mangaratua M. Simanjorang, Ph.D and Prof. Dr. Bornok Sinaga who provided insight and expertise that greatly assisted the research, although they may not agree with all of the interpretations of this paper.

\section{REFERENCES}

[1] Sumaryono, Dasar-dasar Logika, Yogyakarta :Kanisius, 2000.

[2] --------, Kamus Besar Bahasa Indonesia (edisi 3). Departemen Pendidikan Nasional. Jakarta: Balai Pustaka, 2005

[3] Amabile Teresa M, Componential Theory of Creativity, Working papaer, 2012

[4] Rachmawati, Yeni and Euis Kurniati, Strategi Pengembangan Kreativitas Pada Anak Usia Taman Kanak-kanak. Jakarta : Depdikbud, 2005

[5] Stein, M. I., Creativity and culture. Journal of Psychology, 36, 31-322, 1953

[6] Munandar, S.C.U., Pengembangan Kreativitas Anak Berbakat. Jakarta: Rineka Cipta, 1995

[7] Samsunuwiyati Mar'at, Psikologi Perkembangan, Bandung : PT Remaja Rosdakarya, 2006

[8] Slameto, Belajar dan Faktor-faktor yang Mempengaruhinya. Jakarta: Rineka Cipta, 2003

[9] Borg, W. R. dan Gall, M.D., Educational research An Introduction. New York: Longman, 1983

[10] Darsono, Arah Pengembangan Pogram Kemahasiswaan, Rakernas Pimpinan PT bidang Mawa, Yogyakarta 3-5 Desember 2016, Unpublished 